\title{
De brug tussen evidence en praktijk
}

auteurs

ELISE

VAN BELLE

MEREL DIEBELS

INGRID HEIJNEN

MYRTHE

PONDMAN

LINDA

SMULDERS

FRANK VERBEEK

De auteurs zijn werkzaam bij het

Radboudumc

Nijmegen.

Frank Verbeek is ook

verbonden aan de

Hogeschool van

Arnhem en Nijmegen.
Verpleegkundig wetenschappers maken in het Radboudumc de koppeling tussen wetenschap en dagelijkse praktijk. In de toekomstvisie van de auteurs heeft binnen vijf jaar elke klinische afdeling in het ziekenhuis minimaal één medewerker met deze functie in dienst.

\section{@}

CORRESPONDENTIE ELISE VAN BELLE

ELISE.VANBELLE@ RADBOUDUMC.NL

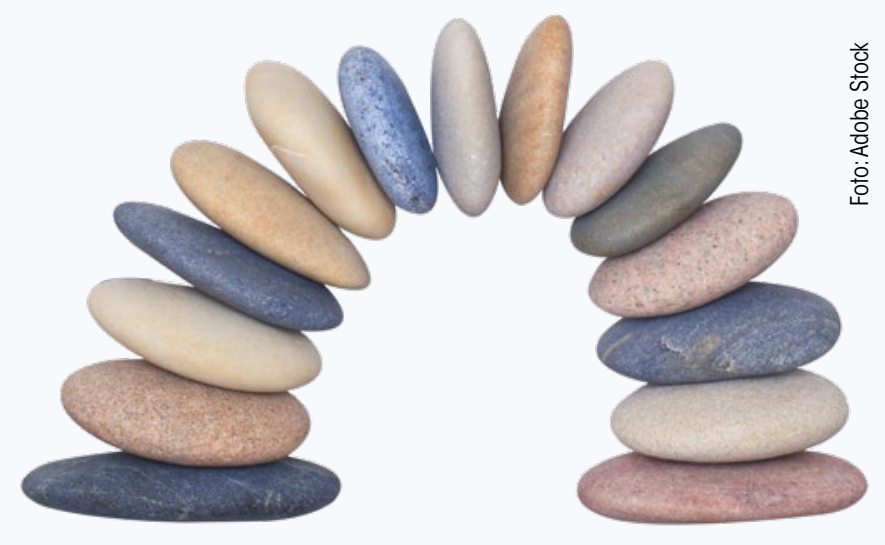

\author{
TREFWOORDEN \\ $\rightarrow$ Ontwikkeling \\ $\rightarrow$ Kwaliteit van zorg \\ $\rightarrow$ Verpleegkundig onderzoek \\ $\rightarrow$ Ziekenhuiszorg
}

Elke dag staan verpleegkundigen oog in oog met uitdagingen. Het lijkt alsof er geen dag voorbijgaat zonder landelijk nieuws over de zorg. Is het niet de vergrijzing van de bevolking, dan zijn het wel nieuwe inzichten over handelingen die we beter kunnen laten, nieuwe functieprofielen of de zorg rondom een nieuw virus, zoals COVID-19. ${ }^{1}$ Dit vraagt van verpleegkundigen om flexibel te zijn, zowel in de organisatie van zorg als in de dagelijkse handelingen. Om dat te bereiken hebben ze kennis en verpleegkundig leiderschap nodig; daarmee kunnen ze invloed uitoefenen op persoonsgerichte zorg, effectiviteit en veiligheid van de zorg. ${ }^{2}$ Verpleegkundigen moeten hiervoor reflectief kunnen kijken naar het dagelijks handelen van zichzelf en collega's en gebruikmaken van evidence based practice (EBP). ${ }^{3}$ In de praktijk blijkt echter dat veel verpleegkundigen het moeilijk vinden EBP te integreren in hun dagelijks werk. Ingeslopen routine maakt het lastig om 
FIGUUR 1 ROLLEN VAN DE VERPLEEGKUNDIG WETENSCHAPPER

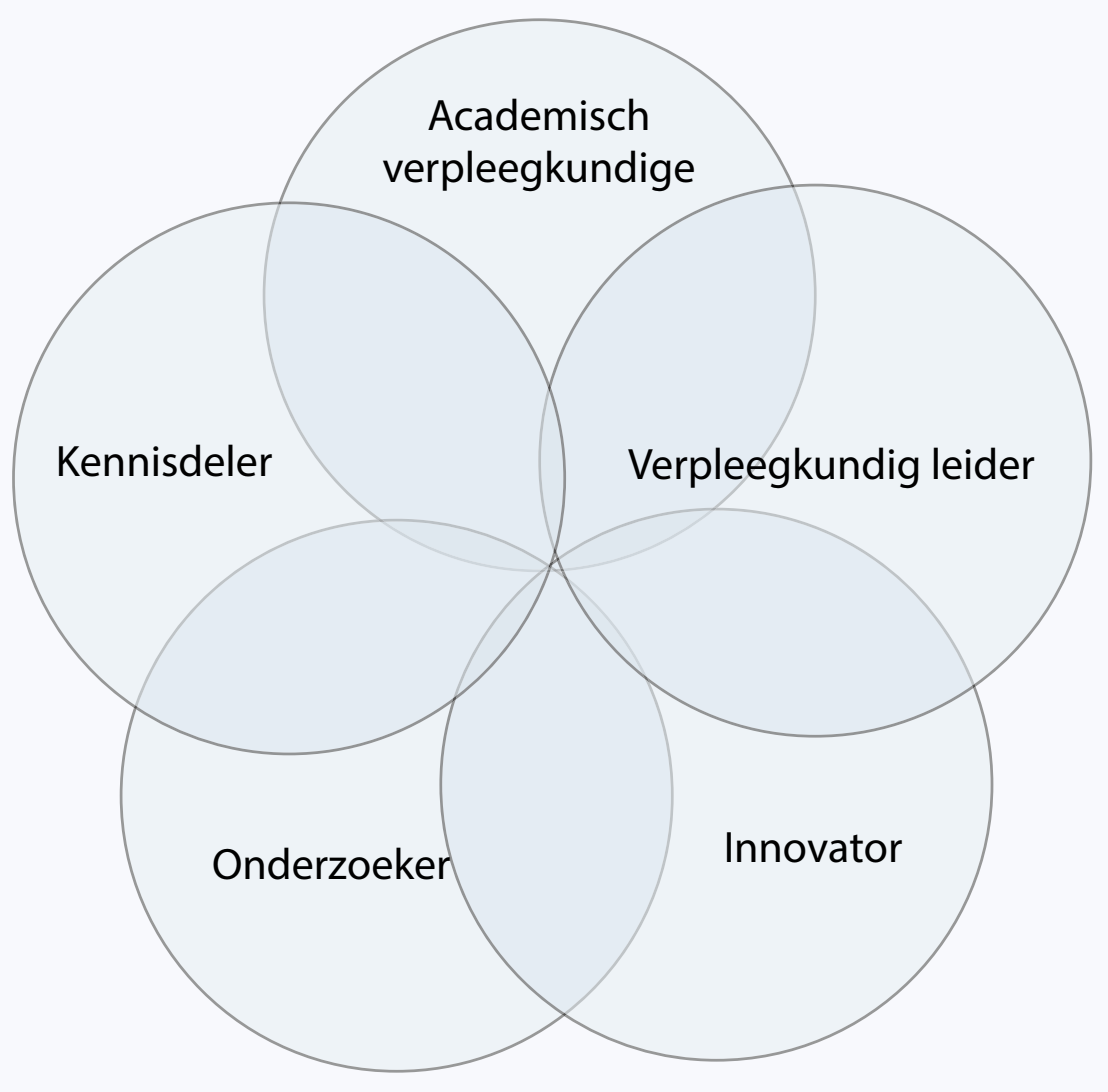

kritisch naar het eigen handelen en dat van collega's te blijven kijken en verwonderingsvragen te stellen. Ook de implementatie van nieuwe wetenschappelijke kennis en innovaties staat niet bovenaan de prioriteitenlijst van menig verpleegkundige. Dagelijks komen er nieuwe inzichten bij waarmee verpleegkundigen beter voor hun patiënten en hun naasten kunnen zorgen. Om de zorg kritisch te evalueren, te blijven verbeteren en innovaties te kunnen doorvoeren, is een brug nodig tussen de wetenschap en de dagelijkse praktijk. Het Radboudumc heeft daarom in 2019 de functie van verpleegkundig wetenschapper gecreëerd.

\section{ACADEMISCHE MASTER}

De verpleegkundig wetenschapper is een verpleegkundige met een wetenschappelijke opleiding gericht op onderzoek. Voorbeelden zijn de universitaire opleidingen klinische gezondheidswetenschappen, verplegingswetenschap en evidence based practice in health care. In het Radboudumc zijn ongeveer 35 verpleegkundigen werkzaam die een dergelijke academische master volgen of hebben behaald. Het merendeel werkt in de directe patiëntenzorg. Vóór het ontwikkelen van de functie liepen zij tegen barrières op, waardoor zij hun kennis en vaardigheden niet goed konden inzetten. Het ging onder andere om een gebrek aan carrièreperspectief, geen structurele begeleiding in functieontwikkeling op de werkvloer en het ontbreken van een netwerk van collega's. Daarnaast was er zowel op de werkvloer als in de organisatie een gebrek aan inzicht in de meerwaarde van een academisch opgeleide verpleegkundige. Hierdoor hadden de verpleegkundigen moeite een draagvlak te vinden bij collega's, werden zij ingezet op medisch onderzoek of verward met verpleegkundig specialisten en researchverpleegkundigen. Als gevolg hiervan zetten verpleegkundigen academische ambities op een laag pitje of zochten ze een andere baan. In beide gevallen verloor de afdeling een vaak zeer enthousiaste en deskundige verpleegkundige en spreken we van een 'waste of talent'. In 2018 is het verpleegkundig functiehuis in het Radboudumc herzien in het kader van toekomstbestendig verplegen. ${ }^{4}$ Om de brug te slaan tussen wetenschap en verpleegkundige praktijk, heeft de academisch opgeleide verpleegkundige hierin een duidelijke plek gekregen. Deze is zó gepositioneerd, dat ze door het aan- en uitdragen van wetenschappelijke kennis een bijdrage kan leveren aan de strategie van het Radboudumc: To have a significant impact on healthcare.

Onder leiding van opleidingsdirecteur zorgberoepen Jolanda ter Sluysen, hoogleraar verplegingswetenschap Hester Vermeulen en dr. Mark van den Boogaard is een werkgroep aan de slag gegaan van academisch opgeleide verpleegkundigen, verpleegkundige $\mathrm{PhD}$-studenten en postdocs. Op basis van het Utrechtse Karakteristiek van de Verplegingswetenschapper, documenten over de positionering van medisch specialisten en wetenschappelijke literatuur over klinisch academische carrièrepaden hebben zij Het karakteristiek van de verpleegkundig wetenschapper in het Radboudumc opgesteld. ${ }^{5}$ Hierin zijn de functie en positionering van verpleegkundig wetenschaper uitgewerkt.

\section{TRIAS ACADEMICA}

In het karakteristiek wordt beschreven hoe de verpleegkundig wetenschapper in het Radboudumc wordt uitgedaagd

\section{'De verpleeg- kundig weten- schapper inspi- reert collega's tot persoonlijk leiderschap'}




\section{ONDERZOEK\&PRAKTIJK}

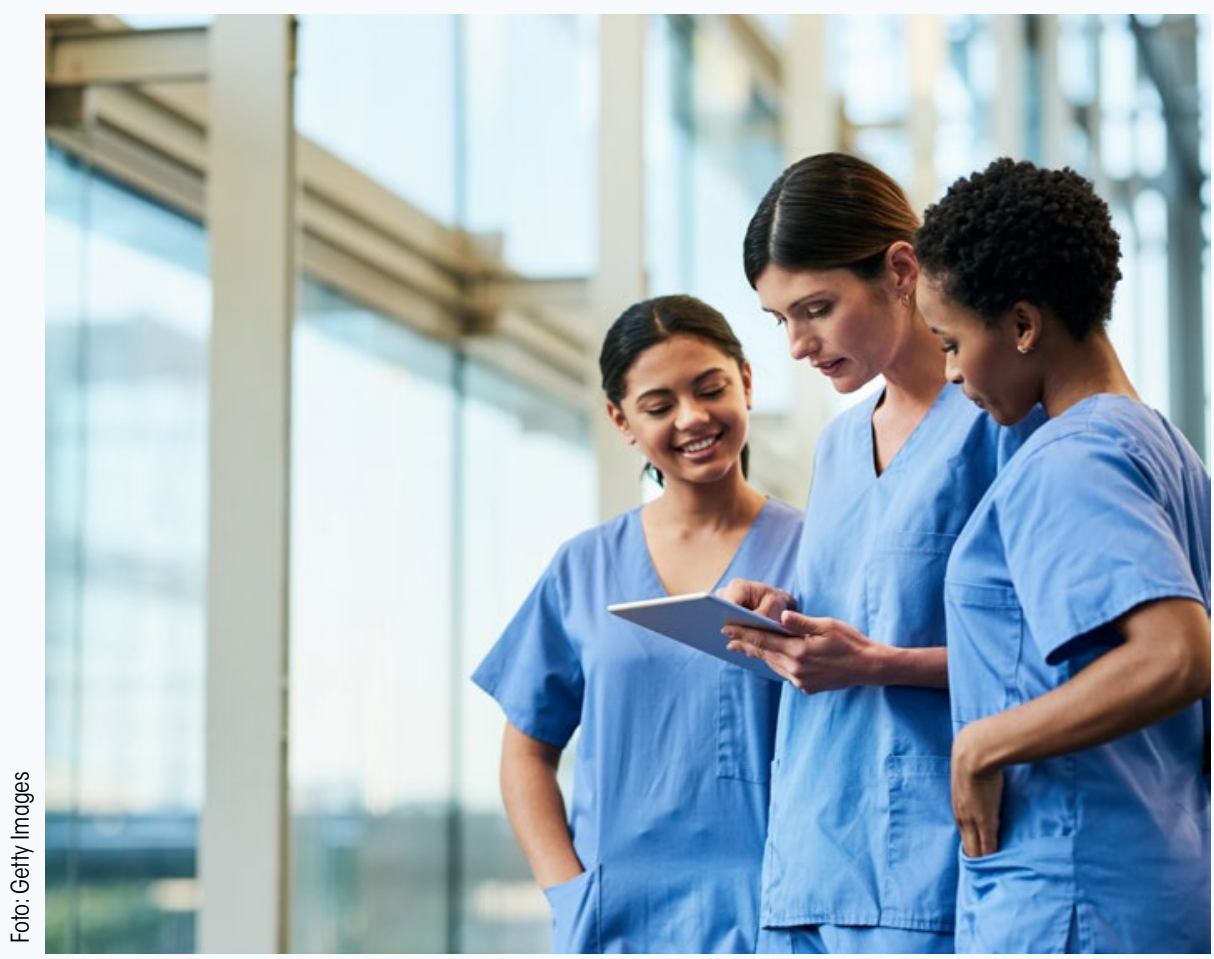

om gestalte te geven aan de trias academica: patiëntenzorg, onderzoek en onderwijs binnen de verpleegkundige zorg. Hierbij wordt rekening gehouden met de visie op verpleegkunde van het Radboudumc. De verpleegkundig wetenschapper is daardoor voorloper op het gebied van persoonsgerichte zorg, innovatie, wetenschap en de veiligheid van de zorg. ${ }^{6}$ Om het geschikt te maken voor praktisch gebruik beschrijft het karakteristiek vijf kernrollen van de verpleegkundig wetenschapper (zie figuur 1).

\section{Academisch verpleegkundige}

De academisch verpleegkundige heeft goede kennis van het verpleegkundig domein. Hij of zij initieert bij het wetenschappelijk onderbouwen van de verpleegkundige zorg op een afdeling en werkt hierbij samen met (academische) professionals. Om dit te realiseren werkt de academisch verpleegkundige gedurende minimaal de helft van het contract in de directe patiëntenzorg; daardoor is hij of zij in staat praktijkproblemen bij collega's of patiënten snel te signaleren en aan te pakken. Andersom is er ook een directe link met de werkvloer om nieuwe kennis te implementeren.

\section{Verpleegkundig leider}

De verpleegkundig leider neemt initiatief in de verpleegkundige beroepsprofessionalisering. Dit uit zich in een voorbeeldfunctie op de werkvloer, waarbij er aandacht is voor het coachen van het team van verpleegkundigen en studenten. Het komt ook naar voren in het inspireren en stimuleren om persoonlijk leiderschap te tonen. De verpleegkundig leider stelt onderzoekende vragen over de zorg op de afdeling en in het ziekenhuis. Bovendien geeft de verpleegkundig leider een voorbeeld in EBP door activiteiten te ondernemen om de (verpleegkundige) kwaliteit van zorg met wetenschappelijke onderbouwing te verbeteren.

\section{Innovator}

De innovator beschrijft kennis over innoveren en implementeren en hoe de verpleegkundig wetenschapper dit kan vertalen naar de eigen praktijk. Het Radboudumc wil vooroplopen in het vormgeven van de gezondheidszorg van de toekomst. Dit doen wij persoonsgericht en innovatief. Dankzij de combinatie van zorg, een kritische blik en wetenschappelijke kennis is de verpleegkundig wetenschapper bij uitstek geschikt om mogelijkheden tot innovatie in de (verpleegkundige) zorg te herkennen en door te voeren op de eigen afdeling of in het ziekenhuis.

\section{Onderzoeker}

Als onderzoeker vertaalt de verpleegkundig wetenschapper de kennis van wetenschappelijk onderzoek naar de praktijk door praktijkproblemen naar onderzoeksvragen om te zetten en door wetenschappelijk onderzoek te initiëren. Dit doen verpleegkundig wetenschappers door met collega's praktijkproblemen te evalueren en het team kritisch te houden: is de huidige zorg werkelijk de beste manier? Als het nodig is, wordt samen met verpleegkundigen en/of studenten een CAT opgesteld of wordt verpleegkundig praktijkonderzoek geïnitieerd. Tevens kan de verpleegkundig wetenschapper aansluiten bij de onderzoekslijnen van de leerstoel verplegingswetenschap of deelnemen aan medische onderzoekslijnen binnen het specialisme. Daarbij ligt de nadruk op het verpleegkundig domein binnen die onderzoekslijn.

\section{Kennisdeler}

De kennisdeler verzorgt onderwijs binnen de eigen afdeling of het ziekenhuis. Hij of zij presenteert en publiceert ook onderzoeksresultaten. Verder is de kennisdeler benaderbaar voor directe collega's en studenten op het gebied van onderzoek, EBP, implementatie en innovatie. De kennisdeler werkt aan de deskundigheid van het team of het introduceren van nieuwe inzichten. Dit gebeurt bijvoorbeeld via coaching, klinische lessen of het schrijven van (afdeling)protocollen.

Iedere verpleegkundig wetenschapper maakt een jaarplan op basis van de vijf rollen. Zo wordt praktische uitvoering gegeven aan het karakteristiek. Hierbij houdt de verpleegkundig wetenschapper rekening met de speerpunten van het eigen specialisme en de leerstoel verplegingswetenschap. Dit resulteert in herkenbaarheid en uniformiteit tussen de verpleegkundig wetenschappers en faciliteert samenwerking. Daarnaast zien 
wij dat verpleegkundig wetenschappers een belangrijke rol spelen bij de implementatie van de nieuwe verpleegkundige functieprofielen. Er blijkt grote behoefte te zijn aan een gemakkelijk te benaderen en regelmatig aanwezige deskundige op het gebied van EBP, klinisch redeneren en leiderschap. De verpleegkundig wetenschapper heeft deze eigenschappen in huis en lijkt hierdoor een succesbepalende factor te zijn voor implementatie.

\section{NETWERKVORMING}

Maandelijks komen de verpleegkundig wetenschappers samen in het platform verpleegkundig wetenschappers. De groep is gevarieerd. Er zijn jonge verpleegkundigen die hun masteropleiding volgen of deze net hebben afgerond. Aanwezig zijn ook meer ervaren verpleegkundig wetenschappers die al jaren in deze rol werken en soms ook promotieonderzoek verrichten of gepromoveerd zijn. Hester Vermeulen en Jolanda ter Sluysen nemen eveneens deel aan dit platform, evenals (verpleegkundige) senioronderzoekers uit het Radboudumc en van de leerstoel verplegingswetenschap (IQ healthcare). Zij coachen en ondersteunen de verpleegkundig wetenschappers en delen kennis en ervaring. De voorzitter van het platform is Elise van Belle, verpleegkundig wetenschapper op de afdeling Hart Vaat Long van het Radboudumc. Zij zegt: 'Ik werk zeven jaar op mijn huidige afdeling. Toen ik er kwam werken was ik in opleiding tot verplegingswetenschapper en wilde ik graag mijn wetenschappelijke kennis inzetten om de zorg op mijn afdeling te verbeteren. Ik zag dat dit het beste ging als ik zorg en kwaliteitsverbetering combineerde. Wat ik bij mijn patiënten, studenten of collega's signaleer, kan ik meteen omzetten in een

\section{Ik kan nieuwe inzichten snel inbrengen in de praktijk'}

verbeterproject. Andersom kan ik nieuwe (inter)nationale inzichten op een snelle manier de praktijk inbrengen. Ik word blij van onze maandelijkse platformbijeenkomsten, waarin we elkaar helpen, ervaringen delen en samenwerkingen tot stand komen; het laat de hele groep groeien!'

Het platform werkt niet alleen aan samenwerking en rolontwikkeling, maar ook aan netwerkvorming. Dit gebeurt door verbinding te zoeken met relevante partijen, zoals de VAR en de afdeling kwaliteit en veiligheid, door deel te nemen in commissies en raden, en door samenwerking aan te gaan met het (para)medische domein. Het platform is in gesprek met ziekenhuizen uit de regio met als doel te verbinden en ondersteunen. We delen graag onze kennis en ervaringen.

In onze toekomstvisie heeft binnen vijf jaar elke klinische afdeling in ons ziekenhuis minimaal één verpleegkundig wetenschapper in dienst om te waarborgen dat de zorg blijft passen bij de uitdagingen van deze tijd. Ook worden momenteel carrièrepaden voor verpleegkundig wetenschappers ontwikkeld om nog verder te kunnen groeien. Wij streven ernaar dat afdelingen gaan kijken naar wat de beste zorg voor de patiënt is, ongeacht of dit gaat om medische behandeling of verpleegkundige zorg. De verpleegkundig wetenschapper is daar een noodzakelijke schakel in door met kennis en kunde het voortouw te nemen en interprofessioneel samen te werken in onderzoek en de patiëntenzorg.

\section{REFERENTIES}

1. V\&VN 2020. Beter laten, alle afdelingen. www.venvn.nl.

\section{Vermeulen H, Holleman $\mathbf{G}$ \&}

Huis A. Verpleegkundig leiderschap. Houten: Bohn Stafleu van Loghum.

2020. p. 170.

3. Lalleman P. Wat is verpleegkundig leiderschap? www.verpleegkundigleiderschap.nu.

4. Radboudumc. Toekomstbestendig verplegen. www.radboudumc.nl. 5. Bouma J, Craen de E, KruifHoek de E, e.a. Karakteristiek van de verplegingswetenschapper. 2017.

6. V\&VN algemeen Wetenschappelijk College Verpleegkunde V\&VN._Verpleegkundigen werken aan wetenschappelijke inhaalslag. www.venvn.nl.

\section{Samenvatting \\ $\rightarrow$ Veel verpleegkundigen vinden het moeilijk evidence based practice te integreren in hun dagelijks werk. $\rightarrow$ Om een brug te slaan tussen wetenschap en dagelijkse praktijk heeft het Radboudumc de functie van verpleegkundig wetenschapper. $\rightarrow$ Een verpleegkundig wetenschap- per heeft vijf kernrollen: academisch verpleegkundige, verpleegkundig leider, innovator, onderzoeker en \\ $\rightarrow$ Afdelingen in het Radboudumc moeten gaan kijken naar wat de bes- te zorg voor de patiënt is, ongeacht of dit gaat om medische behandeling of verpleegkundige zorg. De ver- pleegkundig wetenschapper is daar een noodzakelijke schakel in door met kennis en kunde het voortouw te nemen en interprofessioneel samen te werken in onderzoek en de patiënten- zorg.} kennisdeler. 